\title{
Immediate Effects of Prescribed Burning on Chemical Properties of the Cerrado Soil
}

\author{
Sandra Ruth Saavedra Magallanes ${ }^{1}$ (1) 0000-0001-6462-3109 \\ Marcos Giongo ${ }^{1}$ (1) 0000-0003-1613-6167 \\ Edmar Vinícius de Carvalho ${ }^{1}$ (1) 0000-0002-4563-2015 \\ Eliane Aparecida Rotili ${ }^{1}$ (i) 0000-0002-8466-7210 \\ Ana Claudia Fernandes ${ }^{1}$ (1) 0000-0003-2602-1582 \\ Jader Nunes Cachoeira ${ }^{1}$ (D) 0000-0001-9150-5431 \\ Gil Rodrigues dos Santos ${ }^{1}$ (D) 0000-0002-4960-0985
}

\begin{abstract}
The Cerrado biome increasingly suffers from the environmental impacts of human action. Burning is known as an action used to destroy native vegetation and to clean areas mainly with the purpose of growing soybeans, corn, or raising cattle. In this study we aimed to investigate the influence of low-intensity burning on the chemical composition of a Red-Yellow Latosol in a region characterized as Cerrado sensu stricto. A total of 14 parcels of land were demarcated. In order to analyze the effects of fire on the soil chemical properties, soil samples were collected before and within 24 hours of the burning by means of the same methodology. An increase in organic matter and in the levels of $\mathrm{Ca}^{2+}, \mathrm{Mg}^{2+}, \mathrm{K}^{+}, \mathrm{Mn}^{2+}, \mathrm{Zn}^{2+}, \mathrm{B}^{+}, \mathrm{S}$, as well in the ratios characterizing the soil (CECt, $\mathrm{SB}, \mathrm{Ca}^{+} / \mathrm{T}, \mathrm{Ca}^{+} /$ $\mathrm{Mg}^{+}, \mathrm{V}$, and $\left.\mathrm{Ca}^{+} / \mathrm{K}^{+}\right)$, was observed. Variables that determine the acidity of the soil, such as $\mathrm{pH}$ and $\mathrm{H}+\mathrm{Al}$, presented changes, although not significant $(p>0.05)$.
\end{abstract}

Keywords: fire, micronutrients, soil acidity.

\section{INTRODUCTION AND OBJECTIVES}

The Brazilian Cerrado represents the largest area of savanna in America, spanning approximately 2 million $\mathrm{km}^{2}$ in Central Brazil (Castro et al., 2017). Cerrado is characterized by different types of vegetation - pastures, open tree canopies, and dense forests - where spatial distribution is determined by many factors such as soil type and topography, and fire frequency and intensity (Batista et al., 2018; Meira et al., 2017).

Soil is a basic component of the forest ecosystem and it is subject to changes by fire. However, its effects - which may alter edaphic factors - are still scarcely studied. According to Resende et al. (2017), although the Cerrado ecosystem is adapted to fire, it can lead to loss of nutrients, compaction, and erosion - a problem that affects vast areas of land. Conversely, when correctly used, controlled burning is known to be a useful tool in preventing high-magnitude fire events, since dry biomass accumulation contributes to increase the occurrence of fire (Batista et al., 2013; Camargos et al., 2015).

Effects on the chemical composition of the soil chiefly results from burn severity, which consists of peak temperatures and duration of the fire (Abraham et al., 2018; Certini, 2005). Thus, soil transformation is directly proportional to the intensity of the fires in the area (Lorenzon et al., 2014).

Following the fire, essential nutrients, such as phosphorus, magnesium, calcium, and potassium, can be released by the ashes (Alcañiz et al., 2018). Therefore, burning may favor an increase in fertility - although ephemeral, it is crucial for plant regeneration. However, according to Knicker (2007), the benefits of nutrient mineralization catalyzed by burning can be depleted in the medium term when burning is carried out during the dry season. This is because rain may cause the leaching of nutrients, which results in lower concentrations that may even be inferior to the ones observed in unburned soils.

${ }^{1}$ Universidade Federal do Tocantins (UFT), Gurupi, TO, Brasil 
Although it is a common practice in Brazil, the need for studies whose authors investigate the effects of burning on soil properties is evident, in such a way to improve the management of areas reserved for livestock activities aiming at reducing potential soil damages and contributing to its conservation.

The state of Tocantins represents an important agricultural border area in the country. Few studies have been carried out in Cerrado areas of municipalities in Tocantins measuring the impacts of burning on the chemical properties of the soil. This practice has also been widely used by most producers and pastoralists in the region.

Taking this into consideration, we aimed to determine the immediate effects of fire intensity on the superficial layer of the soil in a Cerrado sensu stricto area in the state of Tocantins, Brazil.

\section{MATERIALS AND METHODS}

The study was conducted in Fazenda Verdes Mares, in the municipality of Sucupira - state of Tocantins located at a latitude of $11^{\circ} 59^{\prime} 36^{\prime \prime}$ South and longitude of $48^{\circ} 58^{\prime} 15^{\prime \prime}$ West, at 257 meters above sea level. According to the Köppen's classification, it is characterized by a tropical wet-dry climate $(\mathrm{Aw})$ (tropical with wet summer and dry winter), and the average annual precipitation is $1,500 \mathrm{~mm}$. The soil is heterogeneous, with variations among Red-Yellow Latosol, Plinthosol, and Cambisol. Nevertheless, the soil of the experimental area has been described as Red-Yellow Latosol. It is worth noting that the study farm holds soy crops and pastures for cattle; however, the parcels of land composing the experimental area were unchanged, i.e., composed of natural vegetation. The study area is classified according to Ribeiro \& Walter's (1998) category of Cerrado sensu stricto. This savanna-like formation is chiefly characterized by an herb layer, predominantly covered by grasses, and a layer of trees and bushes, with irregular and twisted branches and coverage between 10 and 60\% (Eiten, 1994).

Prescribed burning was carried out by the team of Centro de Monitoramento Ambiental e Manejo do Fogo (CeMAF) in October 2015 between 11:05 a.m. and 6:05 p.m. A total of 14 parcels of land with $200 \mathrm{~m}^{2}$ in area $-10-\mathrm{m}$ wide and $20-\mathrm{m}$ long - was delimited. The area was marked at its length in 2-meter intervals for measurements of the fire propagation speed $\left(\mathrm{m} . \mathrm{s}^{-1}\right)$ and height. Before and after burning, the combustible material was randomly collected from each parcel in order to determine the available amount of fuel, humidity, and combustible material consumed by the fire.

Prior to burning, the average air temperature $\left({ }^{\circ} \mathrm{C}\right)$, relative humidity $(\%)$, and average wind speed $\left(\mathrm{m} . \mathrm{s}^{-1}\right)$ were measured by a portable meteorological station (Kestrel $\left.{ }^{\circledR} 4000\right)$ located near the experimental area.

Fire behavior parameters, expressed by the fire line propagation $\operatorname{speed}\left(\mathrm{m} . \mathrm{s}^{-1}\right)$, flame height $(\mathrm{m})$, and fire intensity $\left(\mathrm{kcal} \cdot \mathrm{m}^{-1} \mathrm{~s}^{-1}\right)$, have also been determined. Intensity was obtained from the Byram's equation (1959), considering the calorific value of $3,705 \mathrm{kcal}^{-\mathrm{kg}^{-1}}$ determined by Pivello et al. (2010) for savanna areas.

Soil chemical properties were determined before and after burning (24 hours). For this purpose, three sampling points were used in each one of the 14 parcels of land for collecting samples composed of the first $5 \mathrm{~cm}$ of the superficial layer. Samples were sent to a private laboratory, where the following chemical properties of the soil would be determined: $\mathrm{pH}\left(\mathrm{CaCl}_{2}\right)$ : potential of hydrogen; $\mathrm{H}+\mathrm{Al}$ : potential acidity $\left(\mathrm{cmol}_{\mathrm{c}} \cdot \mathrm{kg}^{-1}\right)$; P: available phosphorus (mg.kg $\left.{ }^{-1}\right) ; \mathrm{S} \mathrm{SO}_{4}^{-2}$ : sulfur (sulphates) (mg.kg $\left.{ }^{-1}\right) ; \mathrm{K}^{+}$: available potassium (mg.kg $\left.{ }^{-1}\right) ; \mathrm{Ca}^{2+}$ : exchangeable calcium $\left(\mathrm{cmol}_{c} \cdot \mathrm{kg}^{-1}\right) ; \mathrm{Mg}^{2+}$ : exchangeable magnesium $\left(\mathrm{cmol}_{c}\right.$. $\left.\mathrm{kg}^{-1}\right) ; \mathrm{Al}^{3+}$ : exchangeable aluminum or acidity $\left(\mathrm{cmol}_{c} \cdot \mathrm{kg}^{-1}\right) ; \mathrm{OM}$ : organic matter (g.kg-1 $)$; OC: organic carbon $\left(\mathrm{g}^{-\mathrm{kg}^{-1}}\right)$; $\mathrm{B}^{+}$: boron (mg.kg-1 $) ; \mathrm{Cu}^{2+}$ : copper (mg. $\left.\mathrm{kg}^{-1}\right) ; \mathrm{Fe}^{2+}$ : iron (mg.kg $\left.{ }^{-1}\right) ; \mathrm{Mn}^{2+}$ : manganese (mg.kg-1 $)$; and $\mathrm{Zn}^{2+}$ : zinc (mg.kg ${ }^{-1}$ ).

Afterwards, we estimated the SB: sum of bases $\left(\mathrm{cmol}^{\circ}\right.$. $\left.\mathrm{kg}^{-1}\right) ; \mathrm{CECt}$ : effective cation exchange capacity $\left(\mathrm{cmol}_{c^{\prime}} \cdot \mathrm{kg}^{-1}\right) ; \mathrm{V}$ : percent base saturation (\%); $\mathrm{m}$ : percent aluminum saturation (\%); $\mathrm{Ca}^{+} / \mathrm{T}$ : calcium saturation in cation exchange capacity (CEC) (\%); $\mathrm{Mg}^{+} / \mathrm{T}$ : magnesium saturation in CEC (\%); $\mathrm{K}^{+} / \mathrm{T}$ : Potassium saturation in CEC (\%); $\mathrm{Ca}^{+} / \mathrm{Mg}^{+}$: calcium magnesium ratios; $\mathrm{Ca}^{+} / \mathrm{K}^{+}$: calcium potassium ratios; $\mathrm{Mg}^{+} / \mathrm{K}^{+}$: magnesium potassium ratios. Lastly, values were classified as very low, low, medium, and high, according to the methodology described by Sousa \& Lobato (2004).

All variables were processed in Microsoft Excel (2010) spreadsheets and analyzed by the XLSTAT software, version 19.01 (2017). T-tests $(p>0.05)$ and the Pearson's correlation were used for data analysis and comparison.

\section{RESULTS AND DISCUSSION}

On the day of the burning, the average air temperature was $41.82^{\circ} \mathrm{C}$; relative humidity, $15.74 \%$; and wind speed, $0.40 \mathrm{~m} . \mathrm{s}^{-1}$ (Table 1). These meteorological variables changed throughout the day, which impacted variables of the fire behavior. According to Soares \& Batista (2007), air temperature varies both in time and in space, whereas the maximum temperature is observed after midday.

According to our results, and based on McArthur \& Cheney's (1966) classification, the burning intensity was very low, accounting for a mean of $84.42 \mathrm{kcal} . \mathrm{m}^{-1} \mathrm{~s}^{-1}$ with a standard deviation of 72.429 (Table 2). Nevertheless, it was not significantly related to the chemical variables. 
Table 1. Description of environmental variables during prescribed burning.

$\begin{array}{ccc}\text { Temperature }\left({ }^{\circ} \mathrm{C}\right) & \text { Humidity }(\%) & \text { Wind }\left(\mathrm{m} . \mathrm{s}^{-1}\right) \\ 41.82 \pm 3.36^{\star} & 15.74 \pm 6.14^{\star} & 0.40 \pm 0.33^{\star}\end{array}$

${ }^{*}$ We found a difference of $5 \%$ among the means \pm standard deviations by the $t$-test.

Table 2. Variables of the fire behavior.

\begin{tabular}{cccc}
$\begin{array}{c}\text { Parcel of } \\
\text { land }\end{array}$ & Height $(\mathrm{cm})$ & $\begin{array}{c}\text { Propagation } \\
\text { speed }\left({\mathrm{m} . \mathrm{s}^{-1}}^{-1}\right)\end{array}$ & $\begin{array}{c}\text { Intensity } \\
\left(\mathrm{kcal}^{-1} \mathrm{~m}^{-1} \mathrm{~s}^{-1}\right)\end{array}$ \\
\hline Mean & $50.72 \pm 18.93^{*}$ & $0.03 \pm 0.03^{*}$ & $84.42 \pm 72.43^{*}$ \\
\hline
\end{tabular}

However, the percentage of combustible material consumed by the fire (CMC) (Table 3), 55.70\%, was the only burningrelated variable presenting a significant correlation $(p<0.05)$ with soil chemical properties. These variables consist in the content of $\mathrm{Ca}^{2+}, \mathrm{Fe}^{2+}, \mathrm{CO}, \mathrm{SB}$, and the $\mathrm{Ca}^{+} / \mathrm{T}$ ratio (Table 4).

Table 3. Description of the quantity of combustible material in the study area.

\begin{tabular}{cc}
\hline Variables & Mean \\
\hline CMA & $7.48 \pm 2.184$ \\
\hline HCM & $5.24 \pm 1.816$ \\
CMC & $55.74 \pm 14.131^{\star}$ \\
\hline
\end{tabular}

${ }^{*}$ We found a difference of $5 \%$ among the means \pm standard deviations by the $t$-test. CMA: combustible material available (t.ha $\left.{ }^{-1}\right)$; HCM: humidity of combustible material (\%); CMC: combustible material consumed (\%).

Oliveira et al. (2005) reported that the action of fire with temperatures above $400{ }^{\circ} \mathrm{C}$ may cause the loss of $\mathrm{P}$ and $\mathrm{N}$ in the Cerrado environment, which affects the quality of the soil. Some authors have pointed out that when the fire consumes the initial biomass, its ashes return a significant amount of nutrients to the soil when compared with burned areas without biomass. This indicates to which extent the vegetation cover is important for the soil (Sampaio et al., 2003; Simon et al. 2016).
Before burning, the chemical variables (Table 5) found in the soil of the experimental parcels of land presented very high acidity, with $\mathrm{pH}$ below 4.5 , and potential acidity $(\mathrm{H}+\mathrm{Al})$ and exchangeable acidity $\left(\mathrm{Al}^{3+}\right)$ on the medium scale. However, aluminum saturation $(\mathrm{m})$ was high, whereas CECt and base saturation (V) presented low levels.

The soil presented an average of 13.5 g. $\mathrm{kg}^{-1}$ of organic matter and $11.14 \mathrm{~g}^{\mathrm{kg}} \mathrm{kg}^{-1}$ of organic content. Considering the macronutrient parameters presented by Sousa \& Lobato (2004), contents of S, $\mathrm{P}, \mathrm{Ca}^{2+}$, and $\mathrm{Mg}^{2+}$ were very low, although $\mathrm{K}^{+}$was at a medium level. The micronutrient variables were found between the very low $\left(\mathrm{Zn}^{2+}\right)$, low $\left(\mathrm{B}^{+}\right.$and $\left.\mathrm{Cu}^{2+}\right)$, medium $\left(\mathrm{Mn}^{2+}\right)$, and high levels $\left(\mathrm{Fe}^{2+}\right)$. Pivello et al. (2010) observed that, during the dry season, after burning in a Cerrado campo sujo area, the $\mathrm{pH}$ was below 4.5 and the potential acidity, above $70 \%$. On the other hand, during the rainy season, the availability of nutrients was higher, including the organic matter content.

In our study, after burning, the organic matter (OM) content increased by $45.7 \%$, followed by the organic carbon (OC), which increased by $20 \%$. Pomianoski et al. (2006) observed the effects of fire on the soil OM in an agroforestry system, and concluded that, after prescribed burning, the availability of organic matter increased by $37 \%$ on the first layer $(0-5 \mathrm{~cm})$. According to Oyedeji et al. (2016), fire quickly accelerates the mineralization of soil organic matter.

Variables that determine soil acidity, such as $\mathrm{pH}$ and $\mathrm{H}+\mathrm{Al}$, changed, although not significantly. However, aluminum saturation $(\mathrm{m})$ significantly decreased; nevertheless, $\mathrm{Al}^{3+}$ reduced by $26 \%$ (Table 5). Faria et al. (2011) found a slight increase in the $\mathrm{pH}$ and exchangeable acidity variables $\left(\mathrm{Al}^{3+}\right)$ after burning, whereas the potential soil acidity $(\mathrm{H}+\mathrm{Al})$ presented significantly lower values. Conversely, Batista \& Soares (1995) did not find a significant difference in characteristics related to soil acidity in a Pinus taeda plantation after burning.

Table 4. Significant correlations $(p<0.05)$ between chemical variables and the combustible material consumed.

\begin{tabular}{|c|c|c|c|c|c|c|}
\hline Variable $^{1}$ & CMC & OC & $\mathrm{Ca}^{+} / \mathrm{T}$ & $\mathrm{Fe}^{2+}$ & $\mathbf{V}$ & $\mathrm{Ca}^{2+}$ \\
\hline CMC & - & $0.0490^{* *}$ & $0.0452^{\star *}$ & $0.0083^{\star *}$ & $0.0496^{* *}$ & $0.0221^{\star \star}$ \\
\hline $\mathrm{OC}$ & -0.5344 & - & $0.0440^{* *}$ & $0.0002^{\star *}$ & $0.0142^{\star *}$ & $0.0084^{* *}$ \\
\hline $\mathrm{Ca}^{+} / \mathrm{T}$ & -0.5421 & $0.5447^{\star}$ & - & $0.0162^{\star *}$ & $0.0002^{* *}$ & $<0.0001^{\star *}$ \\
\hline $\mathrm{Fe}^{2+}$ & -0.6730 & $0.8400^{*}$ & $0.6279^{\star}$ & - & $0.0002^{\star *}$ & $0.0004^{\star \star}$ \\
\hline V & $-0.5332^{\star}$ & $0.6376^{\star}$ & $0.8328^{*}$ & $0.8345^{\star}$ & - & $<0.0001^{* *}$ \\
\hline $\mathrm{Ca}^{2+}$ & $-0.6043^{*}$ & $0.6728^{*}$ & $0.8842^{\star}$ & $0.8176^{\star}$ & $0.9742^{\star}$ & - \\
\hline
\end{tabular}

${ }^{1}$ Below the diagonal: Pearson's coefficient; above the diagonal: T-test value for Pearson's coefficient. ${ }^{*}$ Correlation is significant at the 0.05 level. ${ }^{* *}$ Correlation is significant at the 0.01 level. CMC: combustible material consumed; OC: organic content; $\mathrm{Ca}^{+} / \mathrm{T}$ : calcium saturation in cation exchange capacity (CEC); $\mathrm{Fe}^{2+}$ : iron; $\mathrm{V}$ : bases of saturation; $\mathrm{Ca}^{2+}$ : calcium. 
We observed an increase in the saturation of micronutrients $\mathrm{K}^{+}, \mathrm{Ca}^{2+}, \mathrm{Mg}^{2+}, \mathrm{S}$, and P (Table 5), although only the available phosphorus had no significant difference in the analysis. According to Lorenzon et al. (2014), who aimed to determine the consequent effects of fire on Red-Yellow Latosol, there was an increase in the content of $\mathrm{P}$, from 1.61 to $4.19 \mathrm{mg}$. $\mathrm{dm}^{-3} ; \mathrm{Ca}^{2+}$, from 3.08 to $6.23 \mathrm{cmol}_{c^{\prime}} \cdot \mathrm{dm}^{-3} ; \mathrm{K}$, from 42.40 to $44.40 \mathrm{mg} \cdot \mathrm{dm}^{-3}$; and $\mathrm{Mg}^{2+}$, from 0.65 to $1.24 \mathrm{cmol}_{\mathrm{c}^{\prime}} \mathrm{dm}^{-3}$. Rheinheimer et al. (2003) also observed an increase in the content of $\mathrm{P}$ after burning. However, they have also observed a sharp decrease of this nutrient on the superficial layer up to 60 days after burning. Yet, the soil presented higher $\mathrm{K}^{+}$ values in the burned parcels of land than in the unburned ones. Simon et al. (2016), upon studying the effects of burning in the Cerrado soil, verified that, in the $0.0-0.5 \mathrm{~m}$ depth layer, the $\mathrm{Ca}^{+} / \mathrm{Mg}^{+}$ratio presented higher availability of these nutrients after burning.

Regarding changes in the content of micronutrients, we observed a significant increase in availability of $\mathrm{Zn}^{2+}$,
$\mathrm{Mn}^{2+}$, and $\mathrm{B}^{+}$contents (Table 5). Couto et al. (2006) studied the impact of fire on the availability of soil nutrients in the Pantanal region, and according to their results, there were no changes in $\mathrm{Mg}^{2+}, \mathrm{B}^{+}$, and $\mathrm{Fe}^{2+}$ values. Additionally, they found a slight increase in $\mathrm{Cu}^{2+}$ values.

According to the statistical analyses, we found a significant increase in the $\mathrm{CECt}, \mathrm{SB}$, and $\mathrm{Ca}^{+} / \mathrm{T}$ ratios (Table 5). However, the $\mathrm{K}^{+} / \mathrm{T}$ and $\mathrm{Mg}^{+} / \mathrm{T}$ ratios significantly decreased (Table 5). Simon et al. (2016) verified that, after burning, the superficial layer $(0-5 \mathrm{~cm})$ presented higher CEC values. This result was justified by the increase in availability of bases in the soil, besides the organic matter mineralization after burning. Thus, CEC increased due to the increase in bases and negative loads in the soil, which allowed these elements to be retained. Similar results have also been observed by other authors (e.g., Dick et al., 2008; Rheinheimer et al., 2003). According to these authors, the increase in cation concentration $\left(\mathrm{Ca}^{2+}\right.$ and $\left.\mathrm{Mg}^{2+}\right)$ may be related to the release of oxides from the ashes.

Table 5. Mean chemical variables before and after prescribed burning.

\begin{tabular}{|c|c|c|}
\hline Chemical variables & A priori & A posteriori \\
\hline $\mathrm{pH}\left(\mathrm{CaCl}_{2}\right)$ & 4.01 & 4.06 \\
\hline $\mathrm{P}\left(\mathrm{mg} \cdot \mathrm{kg}^{-1}\right)$ & 2.73 & 3.11 \\
\hline $\mathrm{S} \mathrm{SO}_{4}^{-2}\left(\mathrm{mg} \cdot \mathrm{kg}^{-1}\right)$ & 2.00 & $3.07^{\star}$ \\
\hline $\mathrm{K}^{+}\left(\mathrm{mg} \cdot \mathrm{kg}^{-1}\right)$ & 34.43 & $46.36^{*}$ \\
\hline $\mathrm{Ca}^{2+}\left(\mathrm{cmol}_{c} \cdot \mathrm{kg}^{-1}\right)$ & 0.19 & $0.31^{\star}$ \\
\hline $\mathrm{Mg}^{2+}\left(\mathrm{cmol}_{\mathrm{c}} \cdot \mathrm{kg}^{-1}\right)$ & 0.14 & $0.23^{\star}$ \\
\hline $\mathrm{Al}^{3+}\left(\mathrm{cmol}_{\mathrm{c}} \cdot \mathrm{kg}^{-1}\right)$ & 0.51 & $0.38^{\star \star}$ \\
\hline $\mathrm{H}+\mathrm{Al}\left(\mathrm{cmol}_{\mathrm{c}} \cdot \mathrm{kg}^{-1}\right)$ & 3.90 & 4.35 \\
\hline $\mathrm{OM}\left(\mathrm{g} \cdot \mathrm{kg}^{-1}\right)$ & 13.05 & $24.07^{*}$ \\
\hline $\mathrm{OC}\left(\mathrm{g} \cdot \mathrm{kg}^{-1}\right)$ & 11.14 & $13.93^{*}$ \\
\hline $\mathrm{B}^{+}\left(\mathrm{mg} \cdot \mathrm{kg}^{-1}\right)$ & 0.11 & $0.16^{\star}$ \\
\hline $\mathrm{Cu}^{2+}\left(\mathrm{mg} \cdot \mathrm{kg}^{-1}\right)$ & 0.41 & 0.39 \\
\hline $\mathrm{Fe}^{2+}\left(\mathrm{mg} \cdot \mathrm{kg}^{-1}\right)$ & 53.50 & 63.64 \\
\hline $\mathrm{Mn}^{2+}\left(\mathrm{mg} \cdot \mathrm{kg}^{-1}\right)$ & 4.98 & $8.45^{*}$ \\
\hline $\mathrm{Zn}^{2+}\left(\mathrm{mg} \cdot \mathrm{kg}^{-1}\right)$ & 0.14 & $0.26^{*}$ \\
\hline $\mathrm{SB}\left(\mathrm{cmol}_{c} \cdot \mathrm{kg}^{-1}\right)$ & 0.42 & $0.65^{\star}$ \\
\hline CECt $\left(\mathrm{cmol}_{\mathrm{c}} \cdot \mathrm{kg}^{-1}\right)$ & 4.32 & $5.00^{*}$ \\
\hline $\mathrm{V}(\%)$ & 9.50 & $12.93^{*}$ \\
\hline $\mathrm{m}(\%)$ & 56.07 & $38.71^{\star *}$ \\
\hline $\mathrm{Ca}^{+} / \mathrm{T}(\%)$ & 4.29 & $6.14^{\star}$ \\
\hline $\mathrm{Mg}^{+} / \mathrm{T}(\%)$ & 3.14 & 4.50 \\
\hline $\mathrm{K}^{+} / \mathrm{T}(\%)$ & 2.00 & 2.29 \\
\hline $\mathrm{Ca}^{+} / \mathrm{Mg}^{+}$ & 0.43 & $1.06^{*}$ \\
\hline $\mathrm{Ca}^{+} / \mathrm{K}^{+}$ & 1.61 & $3.05^{*}$ \\
\hline $\mathrm{Mg}^{+} / \mathrm{K}^{+}$ & 3.34 & 2.78 \\
\hline
\end{tabular}

${ }^{*}$ Increase. ${ }^{* *}$ Decrease. Pairs of means followed by ${ }^{*}$ and ${ }^{* *}$ differ by $5 \%$ as per the $\mathrm{t}$-test. $\mathrm{pH}\left(\mathrm{CaCl}_{2}\right)$ : potential of hydrogen; $\mathrm{P}$ : available phosphorus $\left(\mathrm{mg} \cdot \mathrm{kg}^{-1}\right) ; \mathrm{S} \mathrm{SO}{ }^{-2}$ sulfur (sulphates) (mg. $\left.\mathrm{kg}^{-1}\right) ; \mathrm{K}^{+}$: available potassium (mg.kg-1); $\mathrm{Ca}^{2+}:$ exchangeable calcium $\left(\mathrm{cmol}_{\mathrm{c}} \mathrm{kg}^{-1}\right) ; \mathrm{Mg}^{2+}$ : exchangeable magnesium $\left(\mathrm{cmol}_{\mathrm{c}^{\prime}} \cdot \mathrm{kg}^{-1}\right) ; \mathrm{Al}^{3+}:$ exchangeable

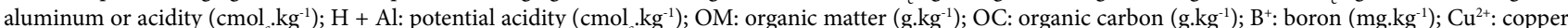

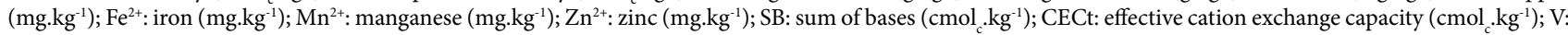
percent base saturation (\%); m: percent aluminum saturation (\%); $\mathrm{Ca}^{+} / \mathrm{T}$ : calcium saturation in cation exchange capacity (CEC) (\%); $\mathrm{Mg}^{+} / \mathrm{T}$ : magnesium saturation in CEC (\%); $\mathrm{K}^{+} / \mathrm{T}$ : potassium saturation in CEC (\%); $\mathrm{Ca}^{+} / \mathrm{Mg}^{+}$: calcium magnesium ratios; $\mathrm{Ca}^{+} / \mathrm{K}^{+}$: calcium potassium ratios; $\mathrm{Mg}^{+} / \mathrm{K}^{+}$: magnesium potassium ratios. 


\section{CONCLUSIONS}

Burning releases nutrients over a period of 24 hours and causes a number of chemical changes to the soil. These changes may be beneficial or harmful to chemical properties, and the degree of variation of their benefit or harm depends on several factors such as the use and type of burned soil, combustible material, time of day, duration, intensity, and frequency.

Low-to-moderate fire intensity may promote an increase in the availability of organic matter and other nutrients, such as $\mathrm{Ca}^{2+}, \mathrm{Mg}^{2+}, \mathrm{K}^{+}, \mathrm{Mn}^{2+}, \mathrm{Zn}^{2+}, \mathrm{B}^{+}$, and $\mathrm{S}$, as well as in the ratios characterizing the soil, $\mathrm{CECt}, \mathrm{SB}, \mathrm{Ca}^{+} / \mathrm{T}, \mathrm{Ca}^{+} / \mathrm{Mg}^{+}$, $\mathrm{V}$, and $\mathrm{Ca}^{+} / \mathrm{K}^{+}$.

\section{ACKNOWLEDGEMENTS}

The authors thank Universidade Federal do Tocantins (UFT), Conselho Nacional de Desenvolvimento Científico e Tecnológico (CNPq), and Coordenação de Aperfeiçoamento de Pessoal de Nível Superior (Capes).

\section{SUBMISSION STATUS}

Received: June 5, 2018

Accepted: Nov. 24, 2018

Associate editor: Marcos Gervásio Pereira

(D) 0000-0002-1402-3612

\section{CORRESPONDENCE TO Gil Rodrigues dos Santos}

Universidade Federal do Tocantins (UFT), Rua Badejós, lote 7, chácaras 69/72, CEP 77400-000, Gurupi, TO, Brasil

e-mail: gilrsan@mail.uft.edu.br

\section{FINANCIAL SUPPORT}

Conselho Nacional de Desenvolvimento Científico e Tecnológico (CNPq)

\section{REFERENCES}

Abraham J, Dowling K, Florentine S. Controlled burn and immediate mobilization of potentially toxic elements in soil, from a legacy mine site in Central Victoria, Australia. Science of the Total Environment 2018; 616-617: 1022-1034. 10.1016/j.scitotenv.2017.10.216

Alcañiz M, Outeiro L, Francos M, Úbeda X. Effects of prescribed fires on soil properties: a review. Science of the Total Environment 2018; 613-614(1): 944-957. 10.1016/j.scitotenv.2017.09.144

Batista AC, Beutling A, Pereira JF. Estimativa do comportamento do fogo em queimas experimentais sob povoamentos de Pinus elliottii. Revista Árvore 2013; 37(5): 779-787. 10.1590/S010067622013000500001

Batista AC, Soares RV. Avaliação do comportamento do fogo em queimas controladas sob povoamentos de Pinus taeda no norte do Paraná. Floresta 1995; 25(1-2): 31-42. 10.5380/rf.v25i12.6443
Batista EKL, Russell-Smith J, França H, Figueira JEC. An evaluation of contemporary savanna fire regimes in the Canastra National Park, Brazil: outcomes of fire suppression policies. Journal of Environmental Management 2018; 205: 40-49. 10.1016/j.jenvman.2017.09.053

Byram GM. Combustion of forest fuels. In: Davis KP, editor. Forest fire: control and use. New York: McGraw Hill; 1959. p.61-89.

Camargos VL, Ribeiro GA, Silva AF, Martins SV, Carmo FMS. Estudo do comportamento do fogo em um trecho de floresta estacional semidecídua no município de Viçosa, Minas Gerais. Ciência Florestal 2015; 25(3): 537-545. 10.5902/1980509819605

Castro AHF, Alvarenga AA, Barbosa JPRAD, Mansur TOF, Paula ACCFF. Avaliação sazonal da atividade da fenilalanina amônialiase e dos teores de fenóis e taninos totais em Stryphnodendron adstringens (Mart.) Coville. Ciência Florestal 2017; 27(3): 1037-1048. $10.5902 / 1980509828679$

Certini G. Effects of fire on properties of forest soils: a review. Oecologia 2005; 143(1): 1-10. 10.1007/s00442-004-1788-8

Couto EG, Cunha LACCN, Loureiro MF. Estudo sobre o impacto do fogo na disponibilidade de nutrientes, no banco de sementes e na biota de solos da RPPN Sesc Pantanal. Rio de Janeiro: Sesc; 2006. (Conhecendo o Pantanal; vol. 2).

Dick DP, Martinazzo R, Dalmolin RSD, Jacques AVA, Mielniczuk J, Rosa AS. Impacto da queima nos atributos químicos do solo, na composição da matéria orgânica e na vegetação. Pesquisa Agropecuária Brasileira 2008; 43(5): 633-640.

Eiten G. Vegetação do cerrado. In: Pinto MN, editor. Cerrado: caracterização, ocupação e perspectivas. Brasília, DF: Editora UnB; 1994. p. 17-73.

Faria ABC, Blum TC, Chitsondzo C, Lombardi KC, Batista AC. Efeitos da intensidade da queima controlada sobre o solo e diversidade da vegetação de campo em Irati - PR, Brasil. Revista Brasileira de Ciências Agrárias 2011; 6(3): 489-494. 10.5039/agraria. v6i3a932

Knicker H. How does fire affect the nature and stability of soil organic nitrogen and carbon? A review. Biogeochemistry 2007; 85(1): 91-118. 10.1007/s10533-007-9104-4

Lorenzon SA, Brianezi D, Valdetaro EB, Souza CM, Martins SV, Ribeiro CAAS et al. Análise química de um solo florestal após ocorrência de fogo. Revista Brasileira de Agropecuária Sustentável 2014; 4(2): 142-147. 10.21206/rbas.v4i2.269

McArthur AG, Cheney NP. The characterization of fire in relation to ecological studies. Australian Forest Research 1966; 2(3): 36-45.

Meira MS Jr, Pereira IM, Machado ELM, Mota SLL, Ribeiro PSSP, Otoni TJO. Impacto do fogo em campo sujo no Parque Estadual do Biribiri, Minas Gerais, Brasil. Floresta e Ambiente 2017; 24 : e00110814. 10.1590/2179-8087.110814

Oliveira IP, Santos KJG, Araujo AA, Oliveira LC. Queimadas e suas consequências na região Centro-Oeste. Revista Eletrônica Faculdade Montes Belos 2005; 1(2): 88-103.

Oyedeji S, Onuche FJ, Animasaun DA, Ogunkunle CO, Agboola OO, Isichei AO. Short-term effects of early-season fire on herbaceous composition, dry matter production and soil fertility in Guinea savanna, Nigeria. Archives of Biological Sciences 2016; 68(1): 7-16. 10.2298/ABS150526002O 
Pivello VR, Oliveras I, Miranda HS, Haridasan M, Sato MN, Meirelles ST. Effect of fires on soil nutrient availability in an open savanna in Central Brazil. Plant and Soil 2010; 337(1-2): 111-123. 10.1007/s11104-010-0508-x

Pomianoski DJW, Dedecek RA, Vilcahuaman LJM. Efeito do fogo nas características químicas e biológicas do solo no sistema agroflorestal da Bracatinga. Boletim de Pesquisa Florestal 2006; (52): 93-118. 10.4336/2012.pfb.52.93

Resende FC, Cardozo FS, Pereira G. Análise ambiental da ocorrência das queimadas na porção nordeste do Cerrado. Revista do Departamento de Geografia 2017; 34: 31-42. 10.11606/rdg. v34i0.131917

Rheinheimer DS, Santos JCP, Fernandes VBB, Mafra AL, Almeida JA. Modificações nos atributos químicos de solo sob campo nativo submetido à queima. Ciência Rural 2003; 33(1): 49-55. 10.1590/ S0103-84782003000100008
Ribeiro JF, Walter BMT. Fitofisionomias do bioma Cerrado. In: Sano SM, Almeida SP, editores. Cerrado: ambiente e flora. Planaltina: Embrapa-CPAC; 1998. p. 89-166.

Sampaio FAR, Fontes LEF, Costa LM, Jucksch I. Balanço de nutrientes e da fitomassa em um argissolo amarelo sob floresta tropical amazônica após a queima e cultivo com arroz. Revista Brasileira de Ciência do Solo 2003; 27(6): 1161-1170. 10.1590/ S0100-06832003000600020.

Simon CA, Ronqui MB, Roque CG, Desenso PAZ, Souza MAV, Kühn IE et al. Efeitos da queima de resíduos do solo sob atributos químicos de um latossolo vermelho distrófico do cerrado. Nativa 2016; 4(4): 217-221. 10.14583/2318-7670.v04n04a06

Soares RV, Batista AC. Incêndios florestais: controle, efeitos e uso do fogo. Curitiba: Independentes; 2007.

Sousa DMG, Lobato E, editores. Cerrado: correção do solo e adubação. 2nd ed. Planaltina: Embrapa Cerrados; 2004. 